\section{Levels of Serotonin during Convulsion and the Effect of Reserpine}

Is view of the contradictory reports ${ }^{1-3}$ with respect to changes in the 5-hydroxytryptamine (5-HT) levels of the mammalian central nervous system during convulsion, this problem was re-examined in rats in which convulsion was induced by intraperitoneal injection of fluoroacetate or 'Metrazol'. The former convulsant was particularly preferred because, unlike the convulsive agents generally employed, its action can be related to specific biochemical events, that is, blocking of the citric acid cycle ${ }^{4}$ with concomitant changes in certain amino-acid ${ }^{5}$ and ammonia ${ }^{6}$-levels of the central nervous system.

The serotonin content of brain, small intestine and spleen of rats treated with convulsants, with or without simultaneous administration of reserpine, was compared with control animals. The solution of reserpine for intraperitoneal injection was prepared by aissolving reserpine crystals $(100 \mathrm{mgm}$.) in $0.1 \mathrm{ml}$. of concentrated formic acid, $2 \cdot 5 \mathrm{ml}$. propylene glycol, $\mathbf{2 . 5} \mathrm{ml}$. absolute alcohol and water to make the volume $20 \mathrm{ml}$. (Formate was used instead of glacial acetic acid to avoid the competition of acetate with fluoroacetate.) The animals which did not receive reserpine received only intraperitoneal injection of reserpine solvent. The animals were killed at $60 \mathrm{~min}$., with the onset of convulsion at $30 \mathrm{~min}$. The amount of fluoroacetate injected was greater than the $L D 50$, $5 \mathrm{mgm}$. $/ \mathrm{kgm}$. for rats, in order to ensure the severity and the recurrence of seizures between onset and time of killing.

Statistical analysis of the values in Table 1 indicates that fluoroacetate-produced convulsion does not cause an increase of serotonin-level in the brain or in the other organs analysed. Administration of reserpine did not produce any delay in the onset of convulsions or in the incidence of seizures. However, it depleted serotonin within $1 \mathrm{hr}$. by 78 per cent from the brain of convulsing animals, but not from the spleen or the intestine, a pattern similar to that produced by reserpine in non-convulsing rats 8 . Administration of reserpine did not alter the fluoroacetate-produced citrate accumulation in the brain to any degres of statistical significance. In another series of experiments 'Metrazol' (60 mgm./kgm.) was administered intraperitoneally alone and with reser. pine. 'Metrazol', like fluoroacetate, had no effect on the 5-HT values of the brain of convulsing rats killed $1 \mathrm{hr}$. after administration of the drug. Again,

Table 1. EFFHCT OF CONvulsion ON 5-HYDROXXTRYPTAMINE CONTENT OF SOME RAT TISSUES AND THE INYLUENCE OF RESERPINE. Sprague-Dawley male rats $(350-400 \mathrm{gm}$.) received intraperitoneally sodium fuoroacetate $(8 \mathrm{mgm} . / \mathrm{kgm}$.) and reserpine $(6 \mathrm{mgm} . / \mathrm{kgm}$.) as indicated. 5-Hydroxytryptamine was determined by the spectrophotofluorometric method (ref. 7) and the citrate, as described

\begin{tabular}{|c|c|c|c|c|}
\hline Group & $\begin{array}{r}\stackrel{5-\mathrm{Hy}}{(\mu \mathrm{gm}} \\
\text { Brain }^{-}\end{array}$ & $\begin{array}{l}\text { droxytryptal } \\
\text { /gm. wet tis } \\
\text { Spleen }\end{array}$ & $\begin{array}{l}\text { nine } \\
\text { sue) } \\
\text { Small } \\
\text { intestine }\end{array}$ & $\begin{array}{c}\text { Citrate } \\
(\mu \mathrm{gm} / \mathrm{gm} . \\
\text { wet tissue }) \\
\text { Brain }\end{array}$ \\
\hline $\begin{array}{l}\text { Control (10) } \\
\text { Fluoroacetate } \\
\text { (10) } \\
\text { Fluoroacet- } \\
\text { ate + reserp- } \\
\text { ine (10) } \\
\text { Reserpine (5) } \\
\text { 'Metrazol' (6) } \\
\text { 'Metrazol' + } \\
\text { reserpine (6) }\end{array}$ & $\begin{array}{l}0.41 \pm 0.03^{*} \\
0.48 \pm 0.03 \\
0.11 \pm 0.05 \\
0.12 \pm 0.05 \\
0.40 \pm 0.02 \\
0.25 \pm 0.05\end{array}$ & $\begin{array}{l}2 \cdot 02 \pm 0 \cdot 22 \\
1 \cdot 78 \pm 0 \cdot 27 \\
1 \cdot 90 \pm 0.28 \\
2 \cdot 34 \pm 0 \cdot 67 \\
2 \cdot 17 \pm 0 \cdot 18 \\
2 \cdot 40 \pm 0.25\end{array}$ & $\begin{array}{l}2 \cdot 08 \pm 0 \cdot 30 \\
2 \cdot 11 \pm 0 \cdot 36 \\
\\
2 \cdot 30 \pm 0 \cdot 30 \\
3 \cdot 00 \pm 0 \cdot 39 \\
3 \cdot 43 \pm 0 \cdot 31 \\
3 \cdot 16 \pm 0 \cdot 26\end{array}$ & $\begin{array}{c}19 \pm 1 \cdot 3 \\
151 \pm 10 \\
119 \pm 13\end{array}$ \\
\hline
\end{tabular}

S.E. convulsions produced by 'Metrazol' had no effeot on the release of 5-HT by reserpine from the brain.

It can safely be stated that there is no statistically proved evidence to demonstrate that fluoroacetate, and, under the conditions of our experiments, 'Matrazol', have any effect on the 5-HT levels of rat brain.

$$
\begin{aligned}
& \text { E. M. GaL } \\
& \text { P. A. DREWho }
\end{aligned}
$$

Neurochemical Research Laboratory,

Veterans Administration Hospital, Sepulveda, California, and

Department of Pharmacology, School of Medicine,

University of California at Los Angeles.

${ }^{1}$ Garattini, S., "5-Hydroxytryptamine", edit. by Lewis, G. P., 246 (Pergamon Press, London, 1958).

${ }^{2}$ Green, J. P., Paasonen, M. K., and Giarman, N. J., Proc. Soc. Exp. Biol. N.Y., 94, 428 (1957)

${ }^{3}$ Bertaccini, G., J. Neurochem., 4, 217 (1959).

- Buffa, P., and Peters, R. A., J. Physiol., 110, 488 (1949).

${ }^{3}$ Dawson, R. N. C., Biochim. Biophys. Acta, 11, 548 (1953).

'Benitez, D., Pscheidt, G. R., and Stone, W. E., Amer. J. Physiol., 176, 488 (1954)

' Bogdanski, D. F., Pletscher, A., Brodie, B. B., and Udenfriend, 8., J. Pharm. and Exp. 'L'her., 117, 82 (1956).

${ }^{8}$ Erspamer, V., Experientia, 12,63 (1956).

\section{Enzymic Release of Sialic Acid and Inactivation of Human Menopausal Gonadotropin}

IT has been shown that the biological activity of chorionic and pituitary gonadotropins is lost when the hormone materials are treated with influenza virus or with receptor-destroying enzyme ${ }^{1-3}$. This enzyme has been recognized as neuraminidase ${ }^{4}$, and the loss of biological activity of gonadotropins on treatment with the above catalytic agents was accompanied by the release of sialic acid. It seemed desirable to investigate the effect of neuraminidase on the chemical composition and biological activity of a purified preparation of human menopausal gonadotropin ${ }^{5},{ }^{n}$.

The relative potency of the preparation used, in terms of human menopausal gonadotropin-24, was 100 when tested by the augmentation of uterus weight in 3-week-old female mice. It contained $7 \cdot 8$ per cent of sialic acid, determined by the diphenyl amine reaction ${ }^{7}$ and expressed as $\mathrm{N}$-acetylneuraminic acid. Heating at $100^{\circ} \mathrm{C} ., p H 2$, for $1 \mathrm{hr}$. destroys the activity and quantitatively removes sialic acid, but it is possible that other bonds (sugar, amino-acid) were broken.

$10 \mathrm{mgm}$. of human menopausal gonadotropin preparation, dissolved in $10 \mathrm{ml} . M / 15$ phosphate buffer, $p \mathrm{H} 6 \cdot 3$, was incubated with about 30,000 units of neuraminidase (receptor-destroying enzyme, Behringwerke) at $35^{\circ} \mathrm{C}$. After $24 \mathrm{hr}$. the solution showed a loss of gonadotropic activity of 80 per cent, as compared with a control kept under the same conditions but without the receptor-destroying enzyme. Reaction mixture was then dialysed twice against 10 vol. of water at $0^{\circ}$ for $48 \mathrm{hr}$. About 60 per cent of initial sialic acid was found in the dialysate. After concentration, the dialysate was applied to a column of 'Dowex 2' 200-400 mesh $(20 \times 0.8 \mathrm{~cm}$.), equilibrated in $0.1 \mathrm{M}$ formic acid ${ }^{8}$. The effluent was collected in $3-\mathrm{ml}$. fractions which were analysed for their sialic acid content. Elution with $0.3 M$ formic acid yields two peaks (fractions 13-19 and 24-29). 